\title{
SEXORCISMOS SELVAGENS: PÓS-PORNOGRAFIA E PERFORMANCE ${ }^{1}$
}

Adriana Pinto Fernandes de Azevedo é doutoranda pelo programa Literatura, Cultura e Contemporaneidade, PUC-Rio. Sua pesquisa tem como enfoque a produção artística e cultural contemporâneas que atravessam questões como pornografia, feminismo e sexualidades..

Email - adrianapfa3@gmail.com

\section{Resumo}

No pornoerotismo e no pós-pornô contemporâneos não existe uma fórmula para o prazer, o prazer é construído. "Os orgasmos, como a terra, são de quem os trabalha", como disse Mireia Sallarés ${ }^{2}$, citada por Maria Llopis em sua "Oficina de pós-pornografia" que aconteceu no Rio de Janeiro em 2012 (comPosições políticas / Festival Panorama de Dança). O principal problema que elas me levam a formular parte da interrogação: é possível produzir novos modos de existência / novos modos de produção subjetiva fazendo uso das tecnologias de produção de subjetividade da modernidade - aliadas às novas tecnologias?

Il n'y a problablement pas une societé qui ne constitue son hétérotopie ou ses héterotopies.

(Michel Foucault)

Na década de 1980, uma parcela do feminismo norte-americano deu início a uma política anti-pornografia. Esse movimento fazia campanhas contra as imagens de violência sexual na mídia mainstream, especialmente nas propagandas. Para essas ativistas, as produções audiovisuais e revistas com conteúdos pornográficos reforçavam a ideia de que o acesso sexual ao corpo da mulher - mesmo quando forçado - era um direito dos homens. Carolyn Bronstein, no livro Battiling Pornography: The American Feminist Anti-Pornography Movement, 1976-1986, cita a feminista Robin Morgan, que resume este sentimento na famosa frase: "Pornography is the theory, and rape the practice [A pornografia é a teoria, o estupro a prática]".

De acordo com David Courbet em seu livro Féminismes et pornographie (2012), ao mesmo tempo em que algumas feministas consideravam a representação pornográfica um instrumento do sistema patriarcal para oprimir as mulheres, outras, ao contrário, a vêem como uma um instrumento que permite às mulheres se liberarem do modelo tradicional da mãe submissa a seu marido, e uma forma de provar que elas também aspiram a uma autonomia de suas vidas sexuais (COURBET,

1 Adriana Pinto Fernandes de Azevedo / Trabalho final da disciplina: Seminário de Tese - 2013.2 / Professor: Karl Erik Schøllhammer

2 Mireia Sallarés. Muertes Chiquitas (doc.), 2011.

3 Mireia Sallarés. Muertes Chiquitas (doc.), 2011. 

la Postpornografía (2010), Esperanza Moreno Hernandez explica mais um pouco o feminismo prosexo e seus desdobramentos:

As ativistas pró-sexo vêm criando, desde o final dos anos 1980, uma incrível diversidade de representações da sexualidade inclassificáveis para a pornografia comercial. Este novo imaginário tem sido denominado pós-pornô (etimologicamente, "depois do pornô"), cremos que o prefixo latino pós- não só faz referência ao seu significado etimológico "depois de", mas consegue reforçar sua contundência discursiva à força de repetição: não podia se chamar de outra forma, porque assim a relação com outros discursos é automática e infalível. Nos referimos a que incluindo o prefixo pósestamos fazendo um chamado a esse emaranhado de termos que vai se alojando no subconsciente do humanismo contemporâneo e que alimentam constantemente os discursos que nos ocupam (arteativista-feminista-pro-sexo): falamos sim, de pós-estruturalismo, pós-feminismo e/ou pósmodernismo. (HERNANDEZ, 2010, p. 59)

O movimento pós-pornô europeu contemporâneo "surge" no final do século XX, com grande presença na Espanha, como uma espécie de continuidade do feminismo pró-sexo da década de 1980, aliada a outros tipos de discurso: o pós-estruturalismo, a teoria queer, o transfeminismo, a teoria pós-colonial, os Estudos Culturais etc. É o efeito do devir sujeito de corpos e subjetividades que até agora só puderam ser objetos abjetos da representação pornográfica: as mulheres, as minorias sexuais, os corpos não-brancos, os transexuais, intersexuais e transgêneros, os corpos disformes e descapacitados...

Não se trata de que estes corpos não estavam representados: eram na realidade o centro da representação pornográfica dominante, mas desde o ponto de vista do olhar masculino heterossexual. A pós-pornografia supõe uma inversão radical do sujeito do prazer: agora são as mulheres e as minorias que se apropriam do dispositivo pornográfico e reclamam outras representações e outros prazeres. (HERNANDEZ, 2010, pp., 59, 60)

As referências que podem ser observadas na pós-pornografia europeia passam pelo anarquismo, o punk, as Riot Grrls, vampiros, monstros, cyborgues, a teoria queer, o feminismo, a pornografia, as práticas SM etc.

$\mathrm{Na}$ América Latina, uma onda de arte pornoerótica ganhou visibilidade quando ocorreram os festivais PorNO PorSI, em Bogotá e em Buenos Aires, em 2011. A arte pornoerótica latinoamericana não é necessariamente uma "importação" da pós-pornografia europeia. Temos uma tradição de arte política de dissidência sexual bastante fértil, corpos que já compunham nosso contexto sócio-político-cultural. Só no Brasil, posso enumerar uma tríade que certamente entra no meu recorte da arte política de dissidência sexual deste país: a figura de Madame Satã, os espetáculos de Dzi Croquettes e da Gang Arte Pornô. O pornoerotismo latino-americano tem como elemento diferencial, então, a cultura do escracho, do deboche, e uma certa alegria que são menos presentes na pós-pornografia europeia - mais combativa, mais "pornoterrorista", pra fazer referência ao trabalho da performer espanhola Diana Junyent aka Diana Pornoterrorista.

Diversos coletivos artísticos e projetos surgiram dos encontros produzidos pelos festivais 
PorNO PorSI. Um deles foi o Antropofagia Icamiaba, idealizado pela artista visual e ativista Taís Lobo. No texto de apresentação do projeto, intitulado Intuições corpóreas acerca de uma autopornografia, Lobo descreve como surgiu a ideia de fazer Antropofagia Icamiaba:

No livro "Sexta-feira - os limbos do pacífico", de Michel Tournier, existe uma imagem que Deleuze conceitua como "sexualidade solar". Essa imagem aparece no momento em que o náufrago Robinson Crusoe, há anos sem contato humano, desenvolve uma relação erótica com alguns elementos e lugares da ilha. Conheci esse conceito há poucos dias e ele me intrigou demais, porque "sexualidade solar" talvez seja a imagem guia do projeto apresentado em maio deste ano, na "EncontrADa - corpo, feminismo e tecnologia", no espaço Nuvem: o projeto Antropofagia Icamiaba - lab honorário, nômade/cigano, um work in progress de uma investigação audiovisual circunscrita nos movimentos da pós-pornografia, da pornografia feminista, da pornografia DIY "faça-vocêmesmx", em que a experimentação audiovisual talvez seja um dispositivo de provocação dos códigos que permeiam e constroem a nossa sexualidade; uma autopornografia que desestabiliza e mareia nossos prazeres e desejos naturalizados, incorporados. Um sexorcismo.

Antropofagia Icamiaba tem como ponto de partida o sexo, os "orifícios que engolem" e os não-orifícios, toda a superfície sensível, a epiderme, em contato com organismos diversos: sintéticos ou naturais - existiria este dualismo nesta ontologia do sexo? Neste projeto, segundo Lobo, procura-se criar experimentações de linguagem e corporais em confronto com as nossas próprias reproduções estéticas e comportamentais:

Considerando que os dois maiores (ainda que ocultos) sustentáculos da estética e do pensamento
hegemônicos sejam o gênero e a sexualidade, cujos maiores suportes de ostentação e de difusão são
o vídeo e a web (tecnologias chave na construção das identidades e na produção das subjetividades),
tendo em vista a pornografia desde uma perspectiva feminista e considerando que tudo está por
construir, principalmente em um ambiente úmido, propício às re-apropriações antropofágicas e
praticante do mesmo, no caso, a América do Sul, é de suma estratégia e importância que as
gramáticas da representação audiovisual, suas tecnologias e dispositivos sejam re-fabricados,
rescritos por mulheres, distintas entre si, à partir de suas singulares experiências de vida. As Icamiabas são mulheres que produzem autopornografia feminista. Pornografia selvagem. A estética das Icamiabas coloca em confronto o selvagem e o tecnológico. Os saberes ocidentais, as noções ocidentais de gênero e sexualidade, de corpo e desejo, com as percepções ameríndias e afrolatinas. Icamiabas (do tupi i + kama + îaba = "peito rachado"): índias que, segundo os mitos brasileiros, teriam formado uma tribo de mulheres guerreiras que não aceitavam a presença de homens e que compunham uma sociedade radicalmente matriarcal. A Antropofagia Icamiaba produz uma barbárie tecnicizada (Oswald de Andrade), selvagens cyborgs.

O conceito de cyborg utilizado aqui foi desenvolvido por Donna Haraway em seu "Manifesto Ciborgue". No texto introdutório do livro Antropologia do Ciborgue: As vertigens do pós-humano, intitulado "Nós, ciborgues: O corpo elétrico e a dissolução do humano", Tomaz Tadeu

4 Lobo faz referência a: Gilles Deleuze. Michel Tournier e o mundo sem outrem. In: DELEUZE, Gilles. Lógica do sentido/ 1974. Ed. Perspectiva, 
da Silva 5 considera, que "é no confronto com clones, ciborgues e outros híbridos tecnonaturais que a "humanidade" de nossa subjetividade se vê colocada em questão" (Da Silva, 2000, p. 10) e prossegue dizendo o seguinte:

Uma das características mais notáveis desta nova era (chamem-na pelo nome que quiserem: a mim, "pós-moderna" não me desagrada) é precisamente a indecente interpenetração, o promíscuo acoplamento, a desavergonhada conjunção entre o humano e a máquina. Em um nível mais abstrato, em um nível "mais alto", essa promiscuidade generalizada traduz-se em uma inextrincável confusão entre ciência e política, entre tecnologia e sociedade, entre natureza e cultura. (Da Silva, 2000, p. 11)

Neste acoplamento, Haraway vê uma possibilidade de saída do labirinto dos dualismos, ou seja, "trata-se não de um sonho de uma linguagem comum, mas de uma poderosa e herética heteroglossia" (Haraway, 2009, 99). Ele vive ao mesmo tempo de um lado e de outro da fronteira que ainda separa o que é máquina do que é organismo. Eles são seres compostos por "implantes, transplantes, enxertos, próteses, seres portadores de órgãos “artificiais”. (...) Estados "artificialmente" induzidos. (...) Seres "artificiais" que superam, localizada e parcialmente (por enquanto), as limitadas qualidades e as evidentes fragilidades do humano" (Da Silva, 2009, p. 12) Para Haraway, entretanto, “o principal problema com os ciborgues é, obviamente, que eles são filhos ilegítimos do militarismo e do capitalismo patriarcal”, mas, estes filhos ilegítimos, segundo a autora, são extremamente infiéis às suas origens. (Haraway, 2009, p. 40)

$\mathrm{Na}$ América Latina o cyborg se junta ao selvagem, antropofagicamente. O pornoerotismo latino-americano tem contribuído para a possibilidade de resgatar o conceito oswaldiano e modernista brasileiro de "bárbaro tecnicizado", e para produzir um cyborg tropical, que resgata mais uma vez o elemento selvagem recalcado por inúmeras investidas civilizatórias e eugenistas em nome do progresso. Qual é este elemento selvagem que está sendo des-recalcado pelo pornoerotismo?

Segundo Eduardo Viveiros de Castro, em um seminário intitulado "Introdução ao pensamento indígena" ${ }^{\circ}$, a imagem do selvagem, nos últimos 200 anos, recebe diversas inflexões, mas é marcada principalmente por duas figuras: a que Antropomorfiza (estende a humanidade para além dos seus limites) e a do Bárbaro, perigoso, que não reconhece a humanidade do outro. Gostaria de me ater à imagem do selvagem que confunde barreiras, que ameaça, que nos fornece uma concepção elástica da humanidade como categoria moral.

No capítulo "O mármore e a murta: sobre a inconstância da alma selvagem", presente no livro A inconstância da alma selvagem, Viveiros de Castro narra as impressões do Padre Antônio

5 Este livro na verdade é a recente edição brasileira onde está o célebre texto da teórica norte-americana, "Manifesto Ciborgue: Ciência, tecnologia e feminismo-socialista no final do século XX”, organizado pelo próprio Tomaz Tadeu (2000).

6 Curso ministrado na PUC/RS em outubro/2012. Disponível em vídeo em:

$<$ http://pensamentoindigena.fiapo.me/video/54541330>. Acessado em: 22/08/2013. 
Vieira em relação aos cativos no Brasil-Colônia. Antônio Vieira constata que os índios que encontrou aqui eram de difícil conversão, mas não por resistirem a ela - pelo contrário, tinham extrema curiosidade de conhecer o Deus cristão - mas pela facilidade que tinham de deixar tudo o que ouviram sobre a religiosidade ocidental pra trás:

O inimigo aqui não era um dogma diferente, mas uma indiferença ao dogma, uma recusa de escolher. Inconstância, indiferença, olvido [...] Eis por que São Tomé fora designado por Cristo para pregar no Brasil; justo castigo para o apóstolo da dúvida, esse de levar a crença aos incapazes de crer - ou capazes de crer em tudo, o que vem a dar na mesma: "outros gentios são incrédulos até crer; os brasis, ainda depois de crer, são incrédulos". (Viveiros de Castro, 2011, p. 185)

Não sendo uma doutrina a inimiga dos catequizadores, os maiores obstáculos eram, segundo Vieira, "as ações e costumes bárbaros da gentilidade": "o canibalismo e guerra de vingança, bebedeiras, poliginia, nudez, ausência de autoridade centralizada e de implantação territorial estável -, e que os primeiros jesuítas rotulavam mais simplesmente 'maus costumes'”. (Viveiros de Castro, 2011, pp. 188-189)

Viveiros de Castro faz questão de assinalar que não se trata de afirmar que, já que o entrave ao cristianismo não era a religião, seria então a cultura ameríndia o verdadeiro empecilho. $\mathrm{Na}$ ontologia ameríndia, cultura e religiosidade estão em continuidade, ao contrário da cultura ocidental:

Sabemos por que os jesuítas escolheram os costumes como inimigo principal: bárbaros de terceira classe, os Tupinambá não tinham propriamente uma religião, apenas superstições. Mas os modernos não aceitamos tal distinção etnocêntrica, e diríamos: os missionários não viram que os "maus costumes" dos Tupinambá eram sua verdadeira religião, e que sua inconstância era o resultado da adesão profunda a um conjunto de crenças de pleno direito religiosas. Os jesuítas, como se tivessem lido mas não entendido bem Durkheim, separaram desastradamente o sagrado do profano (Padgen 1982: 78). Nós, em troca, sabemos que o costume é não só rei e lei, mas deus mesmo. Pensando bem, talvez os jesuítas soubessem disso, no fundo, ou não teriam logo detectado nos costumes o grande impedimento à conversão. (Viveiros de Castro, 2011, p. 192)

O feminismo selvagem presente neste pornoerotismo Antropofágico Icamiaba é um feminismo dissidente, de sujeitos excluídos pelo patriarcalismo, mas também pelo feminismo bempensante. Ele representa, como alerta Preciado (2007), o “despertar crítico do 'proletariado do feminismo' (Virginie Despentes) - o feminismo de putas, lésbicas, violadas, fanchas, dos e das transexuais, de mulheres não-brancas, de muçulmanas... em definitivo quase todas nós”.

O site deste laboratório coletivo de autopornografia e sexorcismo é composto por quatro experimentações audiovisuais: Polifonia, de Luna Acosta; El Sexorcismo de Aily Habibi; Speaker de Luiza Nóbrega; e onira vira rio, de Taís Lobo (todas disponíveis na web).

Segundo Marie-Hélène Boucier, em seu livro Sexpolitiques: Queer Zones 2 (2005), um 
"sexorcismo" promete quebrar os encantos da velha pornografia moderna. A cultura pornográfica, tal como conhecemos, não vem até nós dos muros de Pompeia, mas da modernidade, que engendrou uma certa "vontade de saber" sobre os mistérios da feminilidade. O sexorcismo surge na arte póspornográfica e pornoerótica como um dispositivo importantíssimo de recriação da própria sexualidade e dos desejos. O sexorcismo é uma forma de transportar o corpo e as sensações desse corpo para um estado de criação artística: “Quem me ensinou a desejar?”, pergunta uma voz em Polifonia. A pornografia moderna nos ensinou a desejar? Como produzir imagens que possam competir com o saber engendrado pela pornografia moderna, a fim de tirá-la de seu lugar de dispositivo único de produção repetitiva de masturbação e desejo? Annie Sprinkle, um dos principais sujeitos do feminismo pró-sexo norte-americano, declarou certa vez que "A resposta ao pornô ruim não é o fim do pornô, mas ao contrário, mais pornô!", ou seja, entrar na disputa por produções pornográficas onde os objetos do pornô moderno tornam-se sujeitos, desobjetificados.

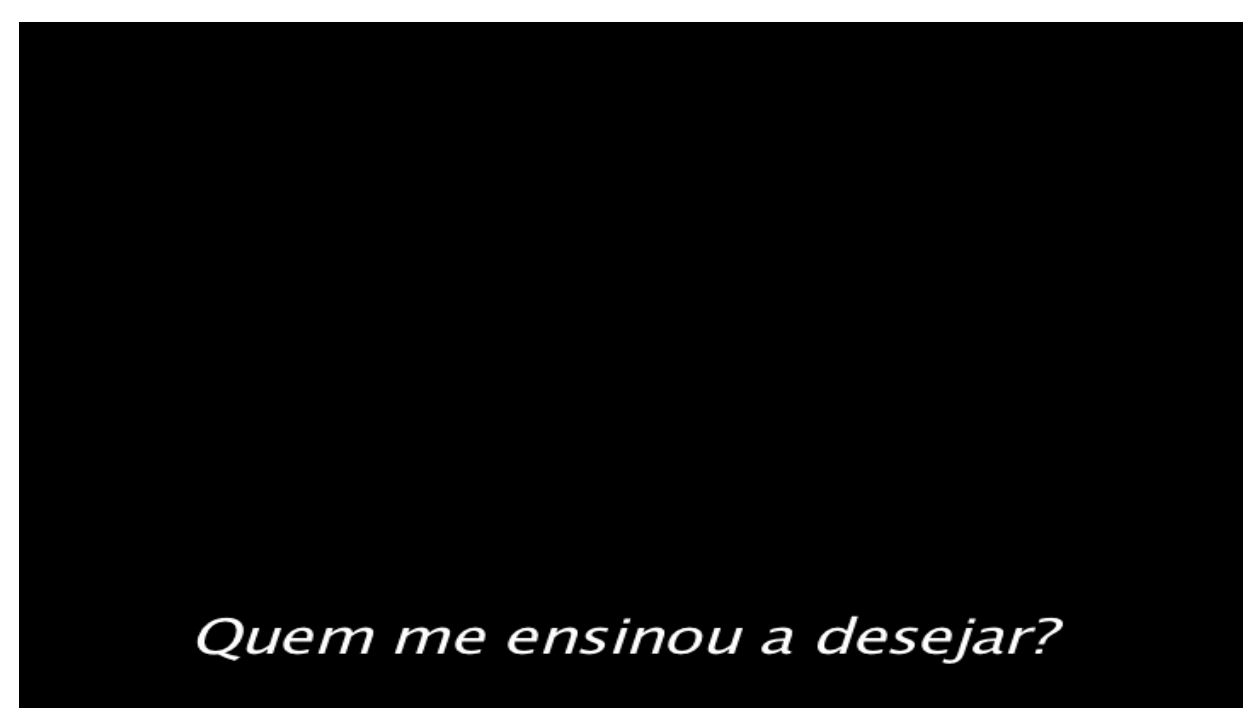

Ilustração 1: Polifonia, Luna Acosta - projeto Antropofagia Icamiaba

A tela escura do vídeo de Luna Acosta alterna sons de prazer e vozes que ecoam, se cruzando e dizendo frases como "Eu não percebo o mundo que não sou capaz de perceber", "Do desconhecido compreendo os traços que são comuns”, “Quem me ensinou a desejar?”, “Quem me ensinou a ver?". No artigo Desenvolvimento do conceito bakhtiniano de polifonia, Vera Lúcia Pires e Fátima Andréia Tamanini-Adames nos explicam melhor o conceito:

Na música, o termo polifonia é usado desde há muito para designar um tipo de composição musical em que várias vozes, ou várias melodias, sobrepõem-se em simultâneo. Em oposição à polifonia, está a monodia, ou a homofonia, na qual as vozes executam o mesmo movimento melódico, seguindo um mesmo padrão rítmico. (PIRES; TAMANINI-ADAMES, 2010, p. 66). 
A polifonia, no sexorcismo de Acosta, poderia ser lida então como uma chave conceitual de contestação contra a monodia da pornografia comercial - que repete o mesmo movimento, o mesmo padrão rítmico em sua composição sexo-coreográfica. A ausência de imagem em Polifonia, a imagem fixa completamente preta (a ausência, e não a "tela em branco" que contém todas as cores, ao invés de nenhuma), põe em suspenso uma enxurrada de vídeos pornográficos comerciais espalhados pela internet em tom monódico. A suspensão da imagem dá espaço para novas: imagens dissidentes, subjetividades sexuais (e desejantes) polifônicas - fazendo referência a Félix Guattari em Caosmose. Um novo paradigma estético, 1992.

No próximo vídeo do projeto, Speaker, de Luíza Nóbrega e Taís Lobo, a câmera foca em um aparelho de som portátil enquanto uma voz narra ideias para um suposto vídeo-arte que vai ser elaborado. Essa voz vai dizendo que a ideia do vídeo é que ela capture alguns sons de gemidos e, enquanto isso, na imagem a que se assiste, aparece primeiramente a cabeça de um cavalo em um pasto, que some e desaparece, e depois surge a imagem do pescoço e da orelha da performer. Depois a câmera mostra um gravador sendo pressionado contra um pescoço, enquanto a outra mão alisa a nuca e a orelha.

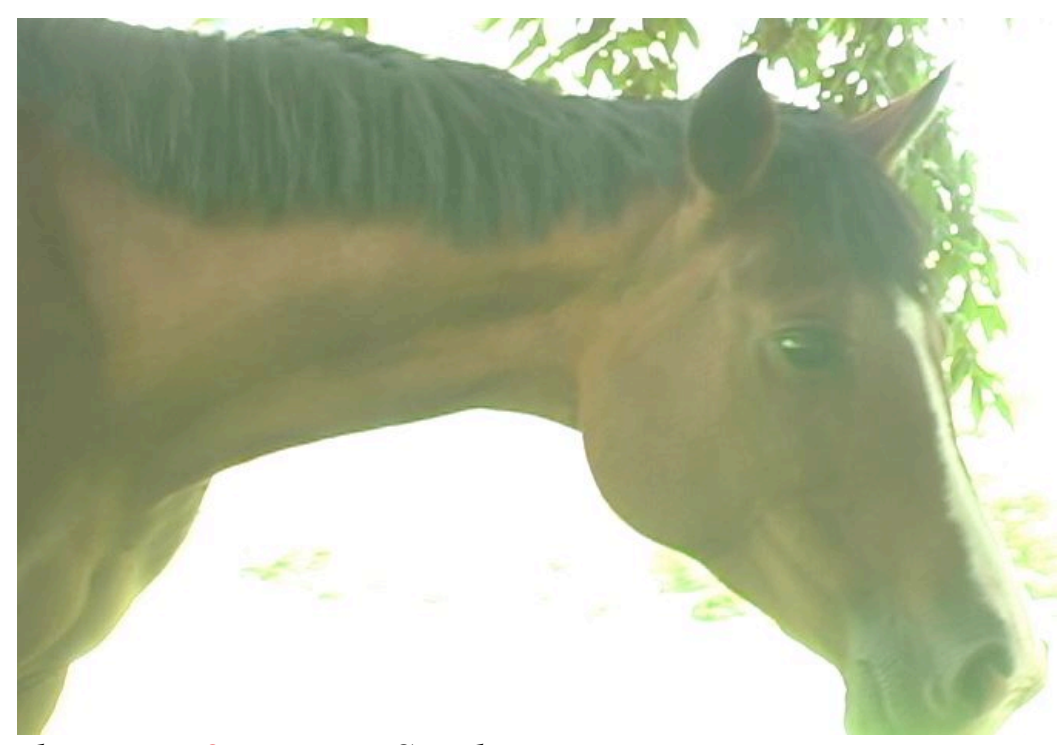

Ilustração 2: Frame - Speaker 


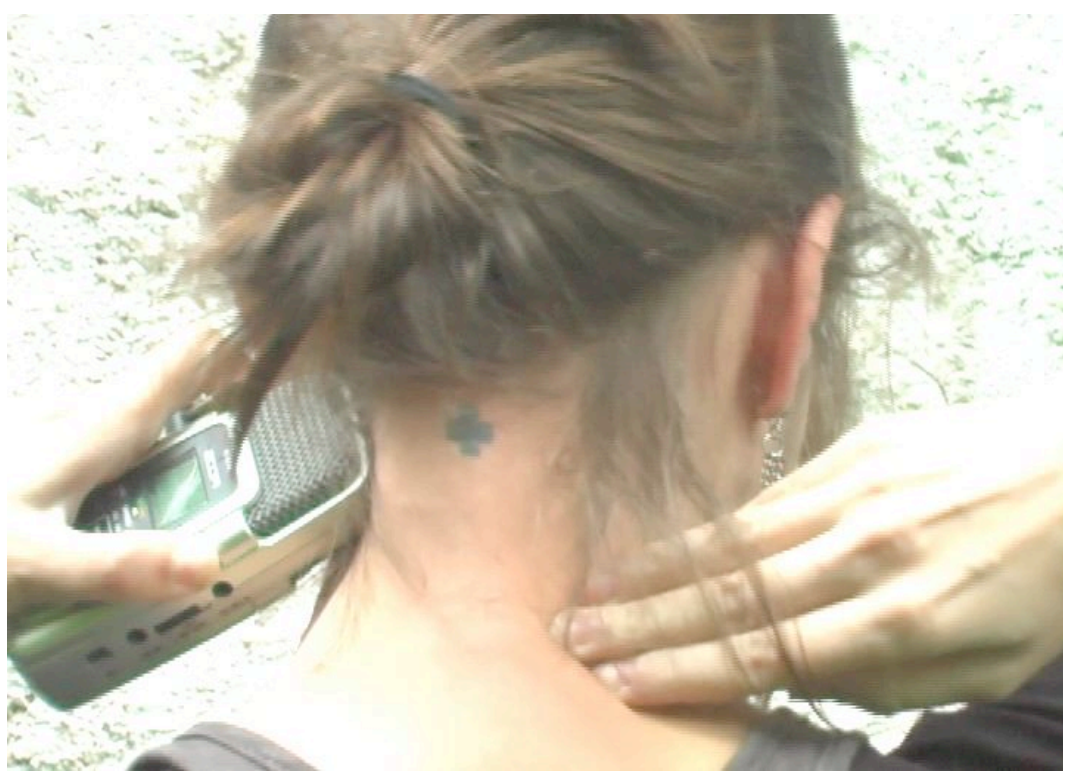

Ilustração 3: Frame - Speaker

O cavalo é um aliado das Icamiabas, guerreiras selvagens, que agem como sujeitos ativos e criadores de seu desejo. Outras partes do corpo são convocadas para a obtenção do prazer: o foco sai dos órgãos genitais. O vídeo nos transporta para uma espécie de masturbação bastante distinta do que estamos acostumados a entender como masturbação: a mão que acaricia o pescoço, a orelha, enquanto o gravador (a máquina, cyborg), estimula a audição emitindo os gemidos que estão registrados nele. "Mi sexualidad es una creación artística", diz o título do documentário de Lucía Egaña, sobre a pós-pornografia em Barcelona. O pornoerotismo latino-americano, sudaca, mestiço, deglutiu esse lema. As Icamiabas são antropógafas: "Só me interessa o que não é meu"7.

Filiação com a pós-pornografia, filiação com a corporeidade afro-ameríndia, como no trabalho de Taís Lobo. Taís Lobo, em seu trabalho de autopornografia intitulado Onira Vira Rio, vídeo-arte de aproximadamente sete minutos, produz uma performance diante de sua câmera, situada no meio de um bosque com árvores frondosas. Na primeira cena da filmagem, vemos o que aparenta ser um vestido que se despe de um corpo. O vestido está largado em um gramado onde chove incessantemente. O tecido e o chão de terra úmida aderem-se. Em seguida, a vídeoperformance é constituída por cenas nas quais Taís pode ser vista nua, se masturbando em meio à floresta. Nós, espectadores, ouvimos o som do chacoalhar das folhas, barulhos que se assemelham ao de animais selvagens, o ruído da água correndo ao longe etc. Imagens do corpo ainda "tenso" de Taís, que tenta se concentrar no toque de si, se alternam com imagens de seu corpo em convulsão, sentada ao chão, encostada ao tronco de uma árvore. A cena muda e agora Taís passa lama pelo seu corpo, enquanto a imagem que estamos vendo, de sua performance, é projetado em seu ventre e em um lençol branco estendido. Não há uma busca pela pureza, há uma busca pelo lado selvagem,

7 ANDRADE, Oswald. Manifesto Antropógago. Revista de Antropofagia, Ano I, No. I, maio de 1928.) 
próximo à terra, a que mescla o corpo com a matéria orgânica, com a água, com a saliva, com os fluidos corporais.

Uma terra vermelha sob o corpo - cor da cabocla icamiaba, o rubro que constrói novos (auto)prazeres no meio do mato verde. (...) A experimentação de outras linguagens, novas comunicações e relações com o meio e os afetos, e o suporte tecnológico e suas (re)apropriações e a experimentação de si e os cruzamentos de tanta experimentação, de tanta tecnologia, de tanta linguagem. ${ }^{8}$

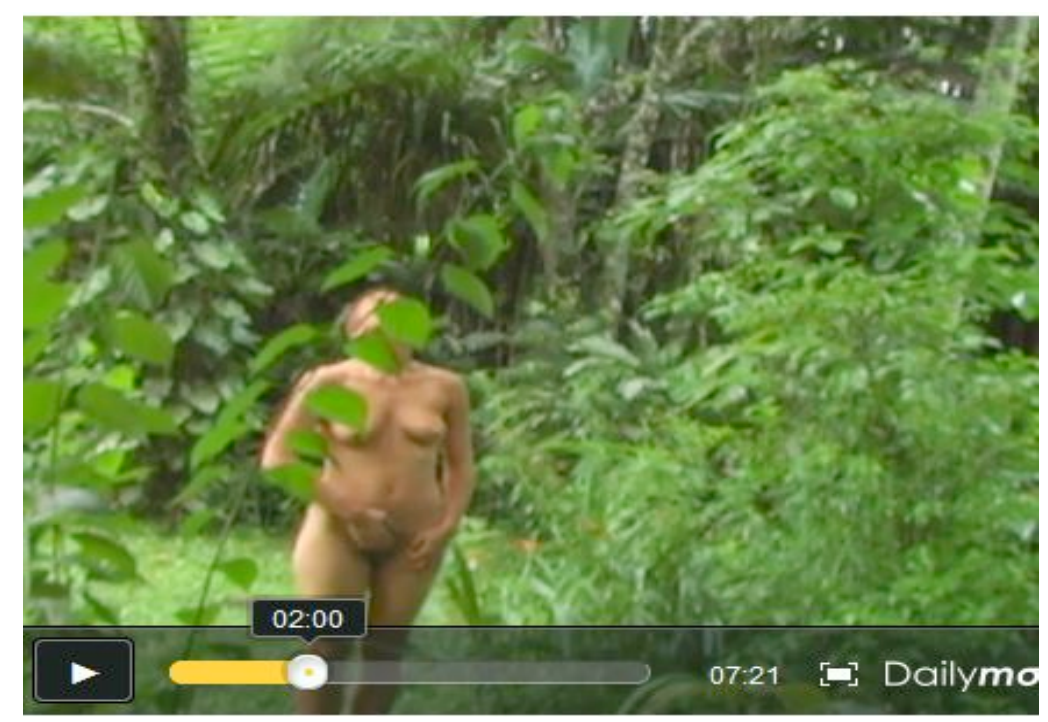

Ilustração 4: Frame de onira vira rio

O corpo de Taís, como no mito de Onira ${ }^{9}$, se banha com a tinta vermelho-sangue ao final da performance. O sangue, aqui, ganha outros contornos, além da referência ao mitológico de origens africanas. O sangue, no mundo ocidental contemporâneo, representa pacto, transmissão, contágio, desejo, fluxo, mulher (menstruação).

Gilles Deleuze e Félix Guattari, no capítulo "Selvagens, bárbaros, civilizados", do livro $O$ Anti-Édipo, consideram que nas máquinas sociais pré-capitalistas, a produção desejante e os fluxos de desejo são codificados: "Codificar o desejo - e o medo, a angústia dos fluxos decodificados - é próprio do socius" (Deleuze; Guattari, 2010, p. 185). Para os autores, o capitalismo seria a única máquina social que se construiu sobre fluxos decodificados. O capitalismo liberaria os fluxos,

mas as condições sociais que definem o seu limite e a possibilidade da sua própria dissolução. (...) Portanto, é procedente compreender retrospectivamente toda a história à luz do capitalismo, mas sob

8 LOBO, Taís. Intuições corpóreas acerca de uma "auto-pornografia. Disponível em:

http://nuvem.tk/wiki/index.php/Tais Lobo. Acessado em: 07/12/2013.

9 Onira: divindade que recebe suas oferendas nas águas dos rios. Guerreira e ao mesmo tempo doce. Amiga de Oxum. Algumas versões do mito narram que Onira ensinou Oxum a lutar 
a condição de se seguir exatamente as regras formuladas por Marx: primeiramente, a história universal é das contingências, e não da necessidade; é a dos cortes e dos limites, e não da continuidade. (Idem, 2010, p. 185)

Deleuze e Guattari, no texto "Devir-intenso, devir-animal, devir-imperceptível”, presente em Mil Platôs: Capitalismo e Esquisofrenia Vol. 4, defendem a existência de "devires-animais muito especiais que atravessam e arrastam o homem, e que afetam não menos o animal do que o homem." (Deleuze; Guattari, 1997, p. 17) Segundo os autores, os devires-animais são reais, e não frutos da imaginação ou sonhos, mas o devir não tem sujeito distinto de si mesmo. Não se trata de uma filiação, mas de uma aliança:

Se o neo-evolucionismo afirmou sua originalidade, é em parte em relação a esses fenômenos nos quais a evolução não vai de um menos diferenciado a um mais diferenciado, e cessa de ser uma evolução filiativa hereditária para tornar-se antes comunicativa ou contagiosa. Preferimos então chamar de "involução" essa forma de evolução que se faz entre heterogêneos, sobretudo com a condição de que se confunda a involução com uma regressão. O devir é involutivo, a involução é criadora. Regredir é ir em direção ao menos diferenciado. Mas involuir é formar um bloco que corre seguindo sua própria linha, "entre" os termos postos em jogo, e sob as relações assinaláveis. [...] Quem não conheceu a violência dessas sequências animais, que o arrancam da humanidade, mesmo que por um instante, e fazem-no esgaravatar seu pão como um roedor ou the dão os olhos amarelos de um felino? (Deleuze; Guattari, 1997, pp. 19-20)

O devir-bicho selvagem de Taís é a contaminação com algo inumano, que não é somente Onira. É uma desconstrução do lugar dado à mulher ocidental como o da mulher pura, que só tem seu corpo limitado ao espaço doméstico, que tem sua sexualidade vigiada, controlada, que não goza, que não se masturba, que não se suja de lama, de sangue menstrual - e que esconde o sangue menstrual, como se ele não existisse. Taís está se contagiando disto que ainda não é seu, que ainda não faz parte do seu corpo:

Natureza que atravessa os reinos. A propagação por epidemia, por contágio [...] O vampiro não filiaciona, ele contagia. A diferença é que o contágio, a epidemia coloca em jogo termos inteiramente heterogêneos: por exemplo, um homem, um animal e uma bactéria, um vírus, uma molécula, um micro-organismo. Ou, como para a trufa, uma árvore, uma mosca e um porco. Combinações que não são genéticas nem estruturais, inter-reinos, participações contra a natureza, mas a Natureza só procede assim, contra si mesma. Estamos longe da produção filiativa, da reprodução hereditária, que só retém como diferenças uma simples dualidade dos sexos no seio de uma mesma espécie, e pequenas modificações ao longo das gerações. Para nós, ao contrário, há tantos sexos quanto termos em simbiose, tantas diferenças quanto elementos intervindo num processo de contágio.

(Deleuze; Guattari, 1997, p 23)

Não há como não lembrar do livro Rewilding (em português, algo como "resselvagizar-se"), da fotógrafa norte-americana Cass Bird. No verão de 2009 e 2010, Cass Bird foi a Sassafras, Tennessee, com um grupo de jovens mulheres, alguns vestidos e uma câmera. As jovens foram escolhidas pela fotógrafa nas ruas de Nova York, de acordo com a sua beleza, humor e fluidez nas 
suas corporalidades e noções acerca da sexualidade. A "escolha pela beleza" serve como atração às fotografias, através do padrão do belo: ela contamina o belo, ela o trai, já que o belo, pelo padrão, exige que os corpos estejam de acordo com o que é "ser uma mulher bela" (feminina) e o que é "ser um homem belo" (masculino). Além disso, essas jovens representam masculinidades em corpos de "mulher", que rasuram o padrão mainstream-falologocêntrico. A sedução estética funciona como arma política. Como ambientação para as fotografias, Cass Bird escolheu a mata, a floresta, as águas dos rios, o casebre de madeira (ver figuras abaixo). As modelos fazem xixi em pé, raspam os cabelos umas das outras, namoram, divertem-se, correm na chuva, sobem em árvores etc.
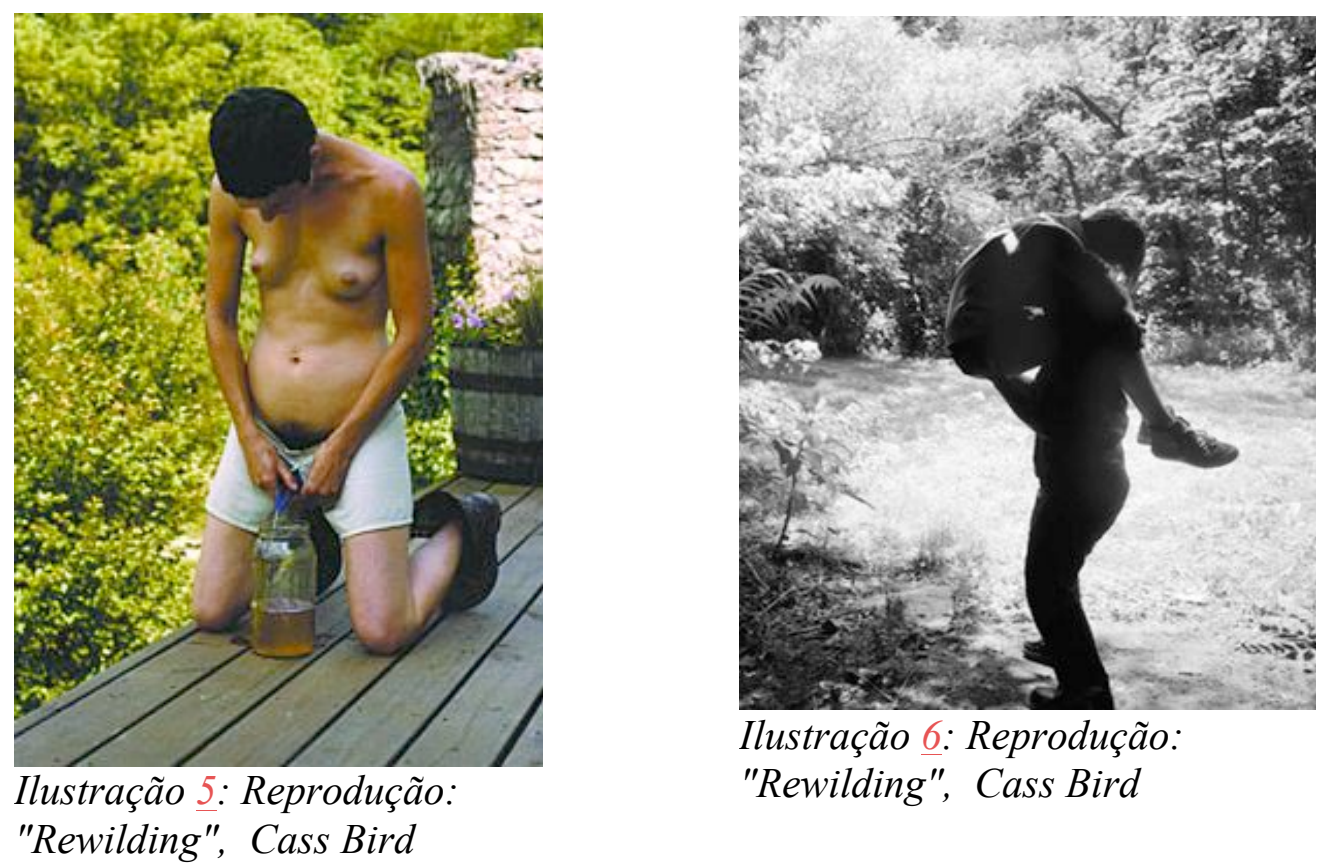

Ilustração 6: Reprodução:

"Rewilding", Cass Bird

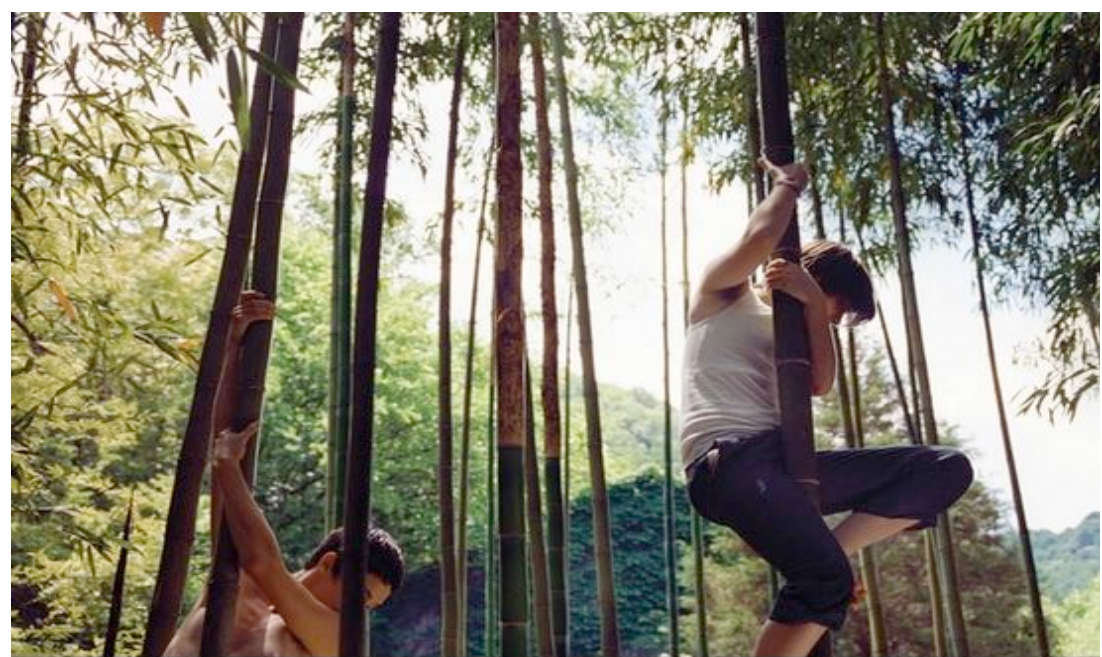

Ilustração 7: Reprodução: "Rewilding", Cass Bird 
De acordo com Jack Halberstam, no prefácio ao livro de fotografias de Cass Bird, as narrativas típicas de tornar-se selvagem são predominantemente masculinas. É a história-clichê do retorno à natureza, da (re)descoberta do instinto de sobrevivência essencial, de autossuperação. O autor dá o exemplo da história narrada em Into the Wild, de John Krakauer. O livro, não-ficional, relata a viagem feita de 1990 a 1992 por Christopher McCandless. Após sua formatura na Universidade de Emory, McCandless deixou de manter contato com seus pais, doou suas economias a uma organização chamada Oxfam e iniciou uma viagem de carro, que acabou abandonando, prosseguindo de carona até o Alasca. No Alasca, o rapaz seguiu a pé pela neve, portando alguns quilos de arroz, uma arma de fogo, livros, uma câmera fotográfica e mais alguns objetos. McCandless foi encontrado morto dentro de um carro abandonado por um grupo de caçadores, - ele sobreviveu cerca de 119 dias no meio da natureza selvagem do Alasca, à procura de plantas comestíveis e frutas - e chegou a caçar um alce, relatando algumas destas experiências em um diário. Krakauer também narra, além desta história central, a de outros rapazes que morreram em viagens semelhantes, como Everett Riess, que desapareceu no deserto de Utah em 1934, aos 20 anos. Halberstam considera que

[a]mbos, Candless e as histórias que as pessoas querem contar sobre ele, supõem uma viagem dentro da selva como um antídoto viril contra o efeminado da vida moderna; e nesta história do homem na natureza, do "homem urso" como a definiu o filme de Werner Herzog, nos topamos com uma romântica e totalmente infantil ode à luta masculina pela sobrevivência: Candless suportou cem dias para morrer na solidão, doente, congelado e perdido. (...) A típica representação de mulheres na natureza selvagem não fez uso desta tradição da sobrevivência, uma tradição de homem branco, escusado será dizer, repleta de relatos de conquista e violência; ao invés disso, geralmente vemos mulheres brancas como presença contraditória à natureza selvagem. É dado à mulher branca o papel da cultura do século XIX, em particular como símbolo da domesticidade, como marcador de tradição, virtude e pureza, seu lugar é o lar. Mulheres na natureza selvagem são representadas como nativas, e as brancas que selvagizam-se são descritas como inapropriadamente sexuais ou masculinas (Calamity James, por exemplo). (Halberstam, 2012 apud Bird, 2012)

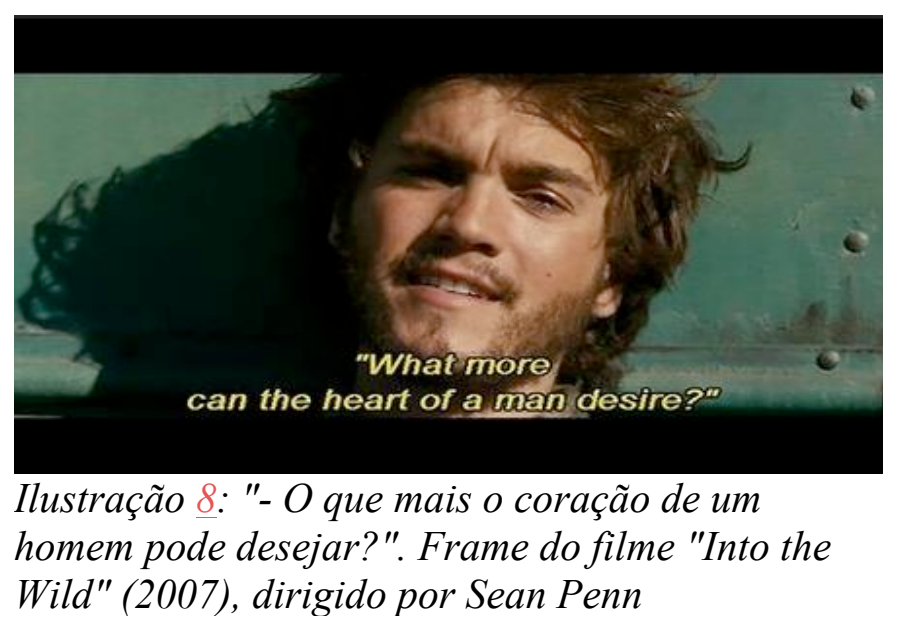

Para Halberstam, a obra de Cass Bird não tem como objetivo representar as jovens como 
selvagens, ao contrário, suas fotografias fazem uso da tradição da natureza selvagem e racial, na tentativa de forjar algo nebuloso na colisão entre os corpos de mulher masculinos neste tipo de ambiente. As fotografias de Bird introduzem os corpos no campo, na natureza, para, com isso, deixar visível o impacto da presença humana sobre a paisagem, e da paisagem sobre os corpos humanos. "E enquanto os bosques pareceriam transbordar de vitalidade, as jovens também vêm a se embriagar com o selvagem, espalhando água, xixi e alegria” (Halberstam, 2012 apud Bird, 2012).

Maria Llopís, em seu vídeo La bestia, também trabalha com a noção da "mulher selvagem".

Como ela mesma descreve, a filmagem é composta por

[u]ma mulher que passeia placidamente por seu jardim e tira subitamente a roupa e fica nua, adotando uma atitude animal, como se tivesse se apoderado dela uma besta interior. Arfa, rosna, faz gestos ameaçadores, cospe e trepa em uma árvore. De repente, parece despertar de seu estado de inconsciência, ruboriza-se por ver-se em tal situação e volta a adotar uma atitude civilizada, comedida e correta. Tanto o comportamento recatado como o bestial estão encenados pela artista: artivicial versus natural, civilizado versus animal, disciplinado versus espontâneo. Podemos nos interrogar como igualmente construídas e estereotipadas estão as atitudes disciplinadas e as subversivas. ${ }^{10}$

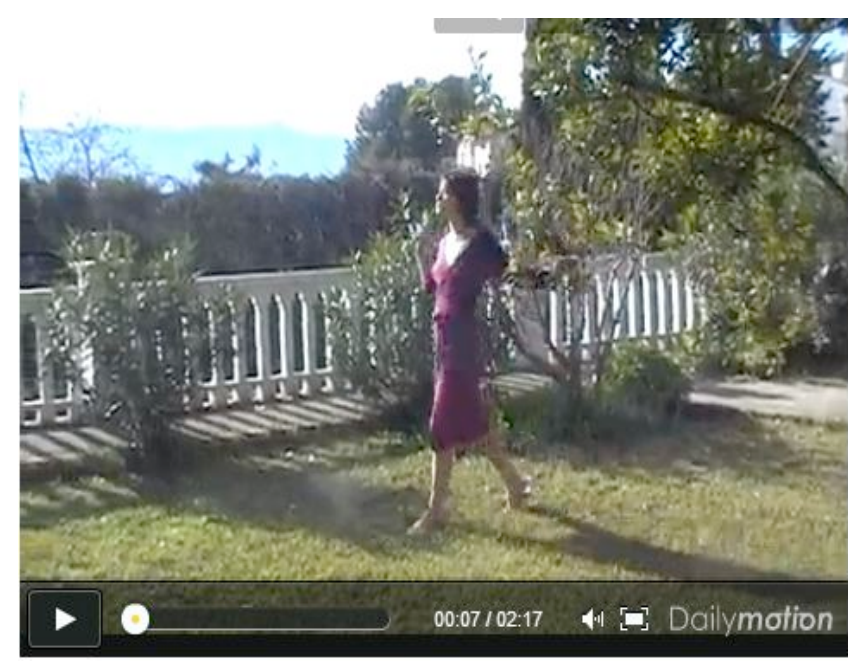

Ilustração 10: Frame de "La bestia"

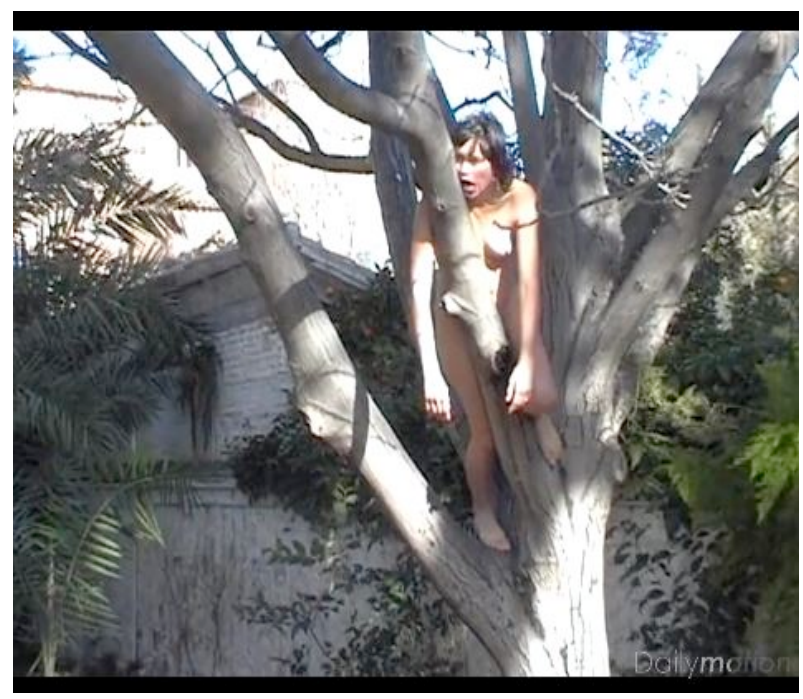

Ilustração 9: Frame de "La bestia"

Llopís "sai de si", mas este "sair de si" é para representar um selvagem estereotipado, o que desperta uma reflexão sobre estes estereótipos, como bem argumenta em sua descrição da cena.

10 "Una mujer que pasea plácidamente por su jardín se quita súbitamente la bata y se queda desnuda, adoptando una actitud animal como si se hubiera apoderado de ella la bestia interior que lleva dentro. Jadea, gruñe, hace gestos amenazantes, escupe e incluso trepa a un árbol. De repente, parece despertar de su estado de inconsciencia, se ruboriza por verse en tal situación y vuelve a adoptar una actitud civilizada, comedida y correcta. Tanto el comportamiento recatado como el bestial están escenificados por la artista: artificial versus natural, civilizado versus animal, disciplinado versus espontáneo. Nos podemos llegar a plantear cómo de igualmente construidas y estereotipadas están las actitudes disciplinadas y las subversivas." (LLOPÍS, Maria, 2005, tradução minha.)

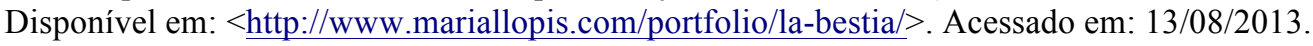


Tanto a mulher "recatada", que faz alusão à mulher moderna, do ambiente doméstico, contida; quanto a mulher selvagem que ela encarna, são os dois lados desta dicotomia, tal como a própria modernidade a criou: a mulher e a besta, o humano e o animal, a mulher contida e a mulher histérica.

Na performance de Taís, a figura da mulher sofre uma disrupção. Trata-se de uma prática de "cuidado de si", uma prática de liberdade, mas que não passa pela re-afirmação do eu, de uma formação de outro sujeito. Esse "cuidado de si” de Taís é uma "saída de si”, mas no sentido de experimentar outras significações, através deste devir-bicho, deste devir-orixá, deste devirselvagem. Trata-se de uma reapropriação do "eu”, de uma formação de outros sujeitos. Para Deleuze e Guattari, "num devir-animal, estamos sempre lidando com uma matilha, um bando, uma população, um povoamento, em suma, uma multiplicidade” (Deleuze; Guattari, 1997, p. 19). Esta matilha não é um gado, e também não é filiativa, mas uma multidão heterogênea.

O que seria um lobo sozinho? E uma baleia, um piolho, um rato, uma mosca? Belzebu é o diabo, mas o diabo como senhor das moscas. O lobo não é primeiro uma característica ou um certo número de características; ele comporta uma proliferação de características, sendo, pois uma lobiferação. (Idem, 1997, p. 20)

Sim, todo animal é ou pode ser uma matilha, mas segundo graus de vocação variável, que tornam mais ou menos fácil a descoberta de multiplicidade, que ele contém atualmente ou virtualmente, dependendo dos casos. Cardumes, bandos, manadas, populações não são formas sociais inferiores, são afectos e potências, involuções, que tornam todo animal num devir não menos potente que o do homem com o animal. (Idem, 1997, p. 22)

“Todas las Caperucitas Rojas se vuelven lobos en la práctica postpornográfica.”, como diz a frase da sinopse do livro de Maria Llopís, "El postporno era eso”. Esta frase carrega mais do que a inversão de papéis entre o Lobo e a Chapeuzinho, figura da menina frágil dos contos infantis, que é comida por um lobo. Tornar-se lobo na prática pós-pornográfica também pode ser lido através deste ato de se resselvagizar, de devir-bicho selvagem - tão usual nas representações do homem buscando sua masculinidade na selva, como descreveu Halberstam ao analisar a obra de Cass Bird, mas tão raro quando se trata das representações do corpo da mulher.

\section{Referências bibliográficas:}


ANDRADE, Oswald de. Do pau-brasil à antropofagia e às utopias. Rio de Janeiro: Civilização Brasileira, 1978.

BORNSTEIN, Carolyn. Battiling Pornography: The American Feminist Anti-Pornography

Movement, 1976-1986. Cambridge, New York, Melbourne, Madrid, Cape Town, Singapore, São Paulo, Delhi, Tokyo, Mexico City: Cambridge University Press, 2011. (Kindle Edition)

BOURCIER, Marie-Hélène. Sexpolitiques: queer zones 2. Paris, La Fabrique 2005.

COURBET, David. Féminismes et pornographie. Paris, LA MUSARDINE, 2012.

DE CASTRO, Eduardo Viveiros. A Inconstância da Alma Selvagem. São Paulo: Cosac \& Naify, 2002.

DELEUZE, Gilles; GUATTARI, Félix. "Selvagens, bárbaros, civilizados", In O Anti-Édipo. São Paulo: Editora 34, 2010.

. "Devir-intenso, devir-animal, devir-imperceptível", In Mil

Platôs. Capitalismo e Esquizofrenia Vol. 4. São Paulo: Editora 34, 1997.

FOUCAULT, Michel. História da sexualidade, A Vontade de Saber. Rio de Janeiro: Edições Graal, 1988.

GUATTARI, Félix. “Da produção da subjetividade”. In Caosmose. São Paulo: Editora 34, 1992.

HALBERSTAN, Jack; BIRD, Cass. Rewilding. Bologna: Damiani Editore, 2012.

HERNANDEZ, Esperanza Moreno. Cuerpos Lesbianos en la Red. De la Representación de la

Sexualidad Lesbiana a la Postpornografía. Dissertação de Mestrado (Máster de Artes Visuales y

Multimedia). Universidad Politecnica de Valencia. Valencia, dezembro de 2010. Disponível no

formato PDF - Creative Commons. Disponível em:

http://www.cuerposlesbianos.net/tesis master esperanza moreno w.pdf . Acessado em 07/12/2013.

LOBO, Taís. Intuições corpóreas acerca de uma "auto-pornografia. Disponível em:

http://nuvem.tk/wiki/index.php/Tais_Lobo. Acessado em: 07/12/2013. 